УДК 633.16:631.5:631.67 (477.7)

DOI https://doi.org/10.32848/agrar.innov.2021.5.8

\title{
ВПЛИВ ПОГОДНИХ УМОВ ТА СТРОКІВ СІВБИ НА ВРОЖАЙНІСТЬ СОРТІВ ЯЧМЕНЮ ОЗИМОГО НА ЗРОШУВАНИХ ЗЕМЛЯХ ПІВДЕННОГО СТЕПУ УКРАЇНИ
}

\author{
кИСІЛь Л.Б. \\ https://orcid.org/0000-0002-2341-3380 \\ Херсонський обласний центр з гідрометеорології \\ ЗАЄЦь С.О. - кандидат сільськогосподарських наук, старший науковий співробітник \\ https://orcid.org/0000-0001-7853-7922 \\ Інститут зрошуваного землеробства Національної академії аграрних наук України
}

Постановка проблеми. Клімат України досить чутливий до глобальних змін, бо підвищення температури тут відбувається більш швидкими темпами [8; 16]. За даними Інституту зрошуваного землеробства НАAН, за останні 35 років у підзоні Сухого Степу спостерігається стійка тенденція до підвищення середньорічної температури з 9,3 ${ }^{\circ} \mathrm{C}$ за період спостережень 1973-1980 pp. до $11,3^{\circ} \mathrm{C}$ - за 2006-2010 рр., тобто на $2^{\circ} \mathrm{C}$ [4]. У період 2011-2020 pр. вона ще підвищилася на $0,7^{\circ} \mathrm{C}$ і становить $12,0^{\circ} \mathrm{C}$ [1]. Багато інших учених відзначають, що клімат в Україні змінюється і зміни відбуваються у бік підвищення [5; 9; 10; 13]. У нормативних документах Всесвітньої метеорологічної організації (ВМО) вказано, що середня температура повітря за рік із початку минулого сторіччя в Степу України збільшилася на $0,2-0,3^{\circ} \mathrm{C}$.

Унаслідок змін клімату в Україні зими стали теплішими, а весни - більш ранніми та здебільшого з підвищеним температурним режимом. Також проявляється тенденція до зміни кількості опадів як у цілому за рік, так і за сезонами, що впливає на режим зволоження ґрунту.

Разом із тим зміни середньорічної кількості опадів не мають чіткої закономірності у часі, але спостерігається тенденція до збільшення опадів зливового характеру та посилення вітрового режиму, що підвищує ризики прояву водної ерозії й дефрляції ґрунтів [3; 11].

Зміни погодних умов, особливо його потепління на тлі тривалого бездощового періоду, є однією з причин низького врожаю зернових культур, у т. ч. ячменю озимого. Окрім того, несприятливі погодні умови під час сівби негативно впливають на ріст, розвиток і формування продуктивності рослин, як результат, урожайний потенціал нових високопродуктивних сортів ячменю озимого не реалізується повною мірою. Останні роки подовжений осінній період потребує певної корекції в технології вирощування сільськогосподарських культур, а саме внесення змін у строки сівби озимих зернових культур у бік пізніших [14].

Зниження ризиків прояву цих негативних явищ потребує запровадження інноваційних технологічних рішень, що забезпечать стабілізацію врожайності та якість вирощеної продукції. Одним із важливих чинників, що позитивно впливає на вирішення цієї проблеми, є використання зрошуваних земель, на яких слід висівати нові високоврожайні сорти зернових культур та забезпечувати рослини всіма факторами життя, у т. ч. і сучасними поліфункціональними препаратами. Визначення напрямів адаптації аграрного виробництва до змін клі- мату та розроблення рекомендацій щодо пом'якшення негативних наслідків змін клімату й ефективного використання додаткового ресурсу у вигляді тепла $є$ актуальними для зони Південного Степу України.

Аналіз останніх досліджень і публікацій. Відомо, що основи майбутнього врожаю ячмінь озимий закладає ще з осені. Якщо у кінці осіннього періоду вегетації рослини добре розкущилися, утворили 3-4 пагони і розвинену вторинну кореневу систему, то слід очікувати високого врожаю зерна. Такі рослини добре переносять сурові зими, менше страждають від пилових бур, i, навпаки, слаборозвинені, не розкущені з осені рослини (у фразі одного-трьох листків) зазвичай гинуть або зріджуються від вимерзання навіть у м'які зими. Тому вегетація рослин ячменю озимого упродовж осіннього періоду повинна становити не менше 40 днів. А це можливо за сівби в оптимальні строки, для того щоб рослини восени могли добре розкущитися та загартуватися [17].

Більше того, строки сівби є одним із чинників впливу на густоту сходів ячменю озимого [7; 15], багато в чому визначають перезимівлю і впливають на підвищення продуктивності ячменю озимого та поліпшення його якості зерна.

Важливість їх значно підвищилася в останні роки, що пов'язано з глобальними змінами клімату [12]. Загальновідомо, що строки сівби як один з агротехнологічних прийомів не потребують додаткових витрат і вважаються найбільш дешевим засобом підвищення продуктивності рослин.

Результати чисельних досліджень свідчать, що від стану посіву ячменю, який сформований на початковому етапі вегетації, великою мірою залежать розвиток рослин у подальшому і кінцевий результат. Неправильно сформовані параметри посіву негативно впливають на ріст і розвиток рослин та врожай зерна [2].

Строки сівби високопродуктивних сортів ячменю озимого нового покоління за вирощування після сої раніше на зрошуваних землях не вивчалися, тому дослідження із цього питання $€$ актуальними.

Мета статті. Визначити вплив сучасних кліматичних змін на формування врожаю зерна сучасних сортів ячменю озимого за різних строків сівби.

Матеріали та методика досліджень. Дослідження проводилися на дослідному полі у сівозміні відділу агротехнологій Інституту зрошуваного землеробства НААН у період із 2016 по 2019 р. Технологія вирощування ячменю озимого загальноприйнята для зрошуваних 
умов зони. Поливами вологість ґрунту на посівах підтримувалася на рівні 70\% НB у шарі 0-50 см, для чого в різні роки потребувалося проведення 1-2 вегетаційних поливи нормою 400 м³/га. Норма висіву становила 5 млн шт./га. Сівбу проводили в два строки: 1 та 20 жовтня. Для дослідження були взяті сорти ячменю типово озимий Академічний та дворучка Дев'ятий вал, які занесенні до Державного реєстру сортів рослин, придатних для використання у Степу відповідно з 2011 і 2015 рр. [6].

Результати досліджень. Агрометеорологічні умови за весняно-літній період вегетації ячменю озимого в роки проведення досліджень були не однаковими. Так, у 2017 р. за березень-червень середньодобова температура повітря становила $13,6^{\circ} \mathrm{C}$, а опадів випало 128,9 мм (табл. 1).

У 2018 і 2019 рр. за цей період температура повітря була вищою і становила 14,5 i $14,6^{\circ} \mathrm{C}$, а опадів випало 121,6 і 228,7 мм, що відповідно на 26,4 мм менше та на 80,7 мм більше за норму.

За формулою Н.М. Іванова коефіцієнт зволоження за вегетаційний період 2017 р. дорівнював 0,47, у тому числі: у березні - 0,10, у квітні - 1,48; у травні $-0,23$, у червні - 0,07 (рис. 1).

У 2018 і в 2019 рр. коефіцієнт зволоження за вегетаційний період ячменю озимого був близьким і становив 0,58 і 0,57. Проте за місяцями він значно різнився: у 2018 р. за березень він становив 1,94, у квітні - 0,01, у травні - 0,24, у червні - 0,11, а в 2019 р. - 0,14, 0,71, 0,81 і 0,60 віповідно.

Тому за таких різних агрометеорологічних умов спостерігався неоднаковий вплив строків сівби на формування врожаю зерна ячменю озимого. Так, в умовах 2017 р. сорт ячменю озимого Академічний у середньому за фактором C (регулятори росту) за сівби 1 жовтня забезпечив врожайність зерна 6,31 т/га, за сівби 20 жовтня - 5,57 т/га, а сорт Дев'ятий вал 6,40 т/га та 5,59 т/га відповідно.

Урожайність зерна за сівби 1 жовтня порівняно 320 жовтня була вищою на сорті Академічний на 0,74 т/га, а на сорті Дев'ятий вал - на 0,81 т/га. У 2018 р., коли ячмінь озимий сформував найвищий рівень продуктивності за роки досліджень, сорт Академічний за сівби 1 жовтня забезпечив урожайність зерна 7,33 т/га, за сівби 20 жовтня - 5,31 т/га, а сорт Дев'ятий вал 7,48 т/га та 6,73 т/га відповідно (табл. 2).

Таким чином, за погодних умов 2018 р. найвищу врожайність зерна 7,33 і 7,48 т/га сорти ячменю озимого Академічний і Дев'ятий вал сформували за сівби 1 жовтня. Порівняно із сівбою 1 жовтня 2017 р. врожайність зерна за сівби 1 жовтня 2018 р. на сорті Академічний була вищою на 1,02 т/га, а на сорті Дев'ятий вал - на 1,08 т/га.

Дещо інша ситуація склалася за сівби 20 жовтня 2018 р., де ячмінь озимий сорту Академічний порів-

Таблиця 1 - Метеорологічні умови за березень-червень у роки досліджень порівняно із середніми багаторічними показниками за 1976-2010 рр.

\begin{tabular}{|c|c|c|c|c|c|c|c|c|}
\hline \multirow{3}{*}{ Місяць } & \multicolumn{8}{|c|}{ Показники } \\
\hline & \multicolumn{4}{|c|}{ середня температура повітря, ${ }^{\circ} \mathrm{C}$} & \multicolumn{4}{|c|}{ сума опадів, мм } \\
\hline & 2017 p. & 2018p. & 2019 p. & норма & 2017 p. & 2018p. & 2019 p. & норма \\
\hline Березень & 7,0 & 1,5 & 5,9 & 2,3 & 5,1 & 61,2 & 7,3 & 28,0 \\
\hline Квітень & 9,3 & 14,1 & 10,5 & 10,0 & 787,9 & 1,6 & 56,0 & 33,0 \\
\hline Травень & 16,3 & 19,5 & 18,0 & 16,0 & 25,6 & 35,7 & 72,8 & 42,0 \\
\hline Червень & 22,0 & 22,9 & 23,8 & 19,9 & 10,3 & 23,1 & 92,6 & 45,0 \\
\hline 3a III-VI & 13,6 & 14,5 & 14,6 & 12,1 & 128,9 & 121,6 & 228,7 & 148,0 \\
\hline
\end{tabular}

Примітки: за даними обласного центру з гідрометеорології м. Херсона

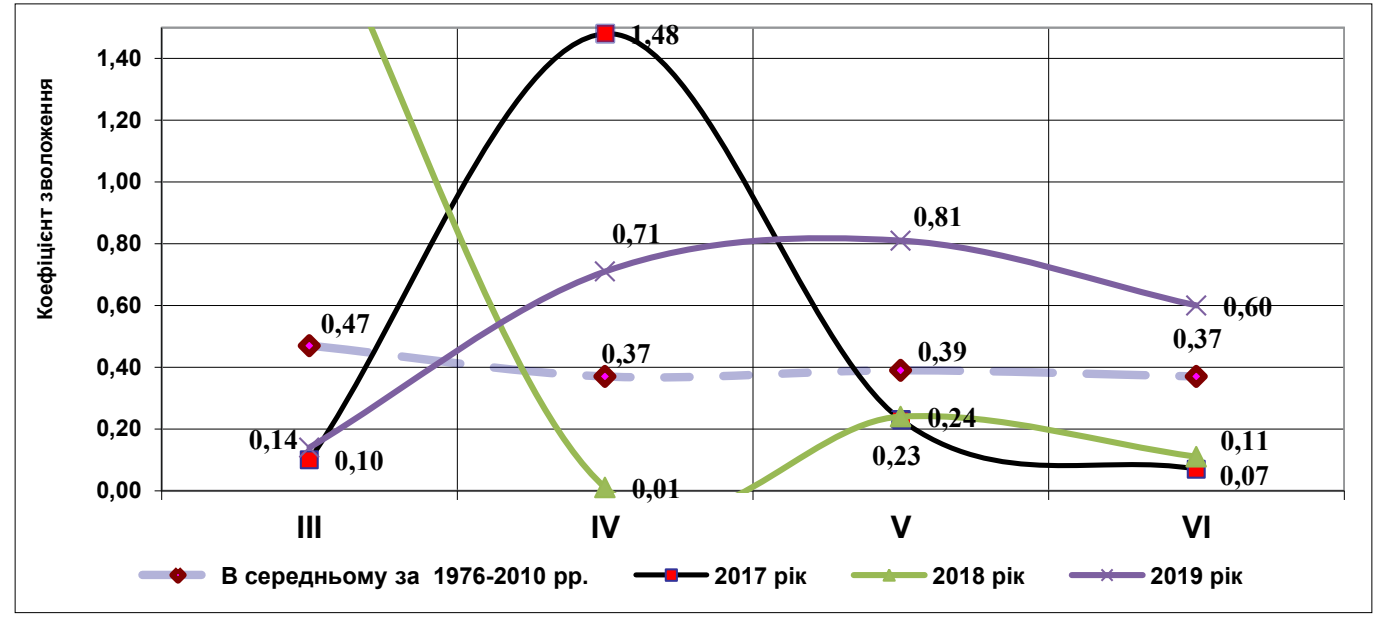

Puс. 1. Коефіцієнт зволоження під час вирощування пшениці озимої

Примітки: за даними обласного центру з гідрометеорології м. Херсона 
Меліорація, землеробство, рослинництво

Таблиця 2 - Урожайність зерна сортів ячменю озимого залежно від строку сівби, т/га

\begin{tabular}{|c|c|c|c|c|}
\hline \multirow{4}{*}{ Роки } & \multicolumn{4}{|c|}{ Строки сівби (В) } \\
\hline & \multicolumn{2}{|c|}{ оптимальний (1.10) } & \multicolumn{2}{|c|}{ пізній (20.10) } \\
\hline & \multicolumn{4}{|c|}{ Сорти (A) } \\
\hline & Академічний & Дев'ятий вал & Академічний & Дев'ятий вал \\
\hline 2017 рік & 6,31 & 6,40 & 5,57 & 5,59 \\
\hline 2018 рік & 7,33 & 7,48 & 5,31 & 6,73 \\
\hline 2019 рік & 5,75 & 6,62 & 5,30 & 6,31 \\
\hline Середнє за 2017-2019 рр. & 6,47 & 6,83 & 5,39 & 6,21 \\
\hline
\end{tabular}

HIP 05 часткових відмінностей, т/га, у 2017 р. для: А - 0,80; В - 0,62; 2018 р. для: А - 0,29; В - 0,32; 2019 р.

для: $\mathrm{A}-0,51 ; \mathrm{B}-0,45$; середнє за 3 роки: $\mathrm{A}-0,33$; $\mathrm{B}-0,40$

няно 32017 р. сорормував на 0,26 т/га нижчу врожайність (2017 р. - 5,57 т/га, 2018 р. - 5,31 т/га). Водночас сорт ячменю озимого Дев'ятий вал за цього ж строку сівби забезпечив максимальну врожайність зерна за всі роки досліджень, яка становила 6,73 т/га, що на 1,14 і 0,42 т/га більше, ніж у 2017 і 2019 рр.

В умовах 2019 р. помітно вищу врожайність формував сорт Дев'ятий вал. Так, за сівби 1 жовтня він забезпечив урожайність зерна 6,62 т/га, за сівби 20 жовтня 6,31 т/га, а сорт Академічний - 5,75 і 5,30 т/га, що відповідно на 0,87 і 1,01 т/га нижче. Урожайність зерна за сівби 1 жовтня порівняно з 20 жовтня була вищою у сорту Дев'ятий вал на 0,31 т/га, а в Академічного - на 0,45 т/га.

У роки досліджень сівба ячменю озимого 1 жовтня порівняно з пізнішим (20 жовтня) підвищувала врожайність сорту Академічний на 0,45-2,02 т/га, а сорту Дев'ятий вал - на 0,31-0,81 т/га. Найвищу врожайність зерна сорти формували за сівби 1 жовтня: Дев'ятий вал 6,83 т/га та Академічний - 6,47 т/га. Середній приріст урожайності зерна сорту Академічний залежно від строку сівби становив 1,08 т/га, або 20,0\%, а у сорту Дев'ятий вал він дорівнював 0,62 т/га, або 10,0\%. Тобто строки сівби впливають на підвищення врожайності обох сортів ячменю озимого, але вагоміші прирости зерна забезпечують рослини типово озимого сорту Академічний, тоді як сорт-дворучка $є$ більш пластичним щодо зміни строку сівби, що пов'язано з його біологічними властивостями.

Висновки. За агрометеорологічних умов, що складалися у роки проведення досліджень, строки сівби по-різному впливали на фрормування врожайності зерна сучасних сортів ячменю озимого. Установлено, що найбільшу врожайність зерна сорти ячменю озимого Академічний і Дев'ятий вал забезпечили за сівби 1 жовтня, що в середньому більше на 1,08 і 0,62 т/га, ніж за сівби 20 жовтня. Проте сорт-дворучка Дев'ятий вал $€$ більш пластичним щодо зміни строку сівби. Максимальну врожайність зерна 7,33-7,48 т/га обидва сорти ячменю озимого формували в умовах 2018 р. Вищою врожайністю виділявся сорт-дворучка Дев'ятий вал, у якого в середньому за три роки врожайність становила 6,83 т/га, а типово озимого сорту Академічний - 6,47 т/га.

\section{СПИСОК ВИКОРИСТАНОÏ ЛІТЕРАТУРИ:}

1. Агрометеорологічний бюлетень по території Херсонської області за 2016-2020рр. № 25-33. URL: http://khersonpogoda.ks.ua.
2. Обоснование оптимальных сроков и норм высева озимого ячменя / А.В. Алабушев и др. Земледелие. 2007. № 3. C. 28-29.

3. Вишкваркова О.В. Екстремальні опади та їх кліматичні особливості на території України : автореф. дис. ... канд. геогр. наук : 11.00.07. Севастополь, 2014. 15 c.

4. Вожегова Р.А. Адаптація землеробства степової зони до умов підвищення посушливості клімату. 2012. URL: http://unt.org.ua/adaptats-ya-zemlerobstva-stepovo-zonido-umov-p-dvishchennya-posushlivost-kl-matu.

5. Вожегова Р.А., Коваленко А.М. Зміни клімату в Південному регіоні та напрями адаптації землеробства до них. Адаптивне землеробство. Київ : АКАДЕМПРЕС, 2013. Т. 1. С. 189-190.

6. Державний реєстр сортів рослин, придатних для поширення в Україні на 2015 р. / Державна ветеринарна та фрітосанітарна служба України. Київ, 2015. $324 \mathrm{c}$.

7. Завалипіч Н.О. Особливості перезимівлі рослин ячменю озимого залежно від строків сівби в умовах Північного Степу України. Зернові культури. 2019. Т. 3. № 2. С. 312-317. DOI: https://doi.org/10.31867/2523-4544/0091.

8. Изменение климата, 2007: Обобщающий доклад. Вклад рабочих групп I, II, III в Четвертый доклад об оценке Межправительственной группы экспертов по изменению климата / Р.К. Пачаури и др. Женева, Швейцария : МГЭИК, 2007. 104 с.

9. Іващенко О.О., Рудник-Іващенко О.О. Напрями адаптації аграрного виробництва до змін клімату. Вісник аграрної науки. 2011. № 8. С. 10-12.

10. Коваленко А.М. Адаптація землеробства степової зони до підвищення посушливості клімату. Зрошуване землеробство. 2012. Вип. 58. С. 21-23.

11. Кононова Н.К. Флуктуации циркуляции атмосферы Северного полушария за 1899-2002 гг. Экстремальные периоды / Материалы Всемирной конференции по изменению климата. Москва, 2002. C. 411.

12. Зміна клімату і оптимізація строку сівби озимої пшениці / Ю.Г. Красиловець та ін. Вісник аграрної науки. 2009. № 11. С. 16-19.

13. Нетіс І.Т. Зміна клімату в зоні зрошення. Зрошуване землеробство. 1994. Вип. 39. С. 7-11.

14. Рекомендації з підготовки та проведення сівби озимих культур у степовому регіоні під урожай 2007 року / А.Г. Новаковський та ін. Одеса, 2006. 56 c. 
15. Вплив строків сівби озимого ячменю після різних попередників на його розвиток і урожайність / М.М. Солодушко та ін. Агроном. 2019. № 3. С. 106.

16. Космічний моніторинг посушливих явищ / О.Г. Тараріко та ін. Вісник аграрної науки. 2012. № 10. С. 16-20.

17. Черенков А.В., Бондаренко А.С., Бенда Р.В. Зимостійкість рослин ячменю озимого залежно від строків сівби в умовах північної частини Степу. Агроном. 2011. № 3. 111 с.

\section{REFERENCES}

1. Ahrometeorolohichnyy byuleten po terytoriyi Khersonskoyi oblasti za 2016-2020 rr. [Agrometeorological bulletin on the territory of Kherson region for 2016-2020], 25-33. URL: http://khersonpogoda.ks.ua [in Ukrainian].

2. Alabushev, A.V. et al. (2007). Obosnovaniye optimal'nykh srokov i norm vyseva ozimogo yachmenya [Obgruntuvannya optymalnykh terminiv i norm vysivu ozymoho yachmenyu]. Zemledeliye - Zemlerobstvo, 3 , 28-29 [in Ukrainian].

3. Vyshkvarkova, O.V. (2014). Ekstremalni opady ta yikh klimatychni osoblyvosti na terytoriyi Ukrayiny. [Extreme precipitation and their climatic features on the territory of Ukraine]. Extended abstract of candidate's thesis. Kyiv [in Ukrainian].

4. Vozhehova, R.A. (2012). Adaptatsiya zemlerobstva stepovoyi zony do umov pidvyshchennya posushlyvosti klimatu [Adaptation of agriculture of the steppe zone to the conditions of increasing aridity of climate]. URL: http://unt.org.ua/adaptats-ya-zemlerobstva-stepovozoni-do-umov-p-dvishchennya-posushlivost-kl-matu [in Ukrainian].

5. Vozhehova, R.A. \& Kovalenko, A.M. (2013). Zminy klimatu $v$ pivdennomu rehioni ta napryamy adaptatsiyi zemlerobstva do nykh [Climate change in the southern region and directions of adaptation of agriculture to them]. Kyiv: TOV "AKADEMPRES" [in Ukrainian].

6. State Veterinary and Phytosanitary Service of Ukraine (2015). Derzhavnyy reyestr sortiv roslyn, prydatnykh dlya poshyrennya $v$ Ukrayini na 2015 r. [State Register of Plant Varieties Suitable for Distribution in Ukraine for 2015]. Kyiv [in Ukrainian].

7. Zavalypich, N.O. (2019). Osoblyvosti perezymivli roslyn yachmenyu ozymoho zalezhno vid strokiv sivby v umovakh pivnichnoho stepu Ukrayiny [Osobennosti perezimovki rasteniy yachmenya ozimogo zavisimosti ot srokov seva $v$ usloviyakh severnogo stepe Ukrainy]. Zernovi kultury - Zernovyye kul'tury, 3, 312-317 [in Ukrainian].

8. Pachauri, R.K. \& Rayzinger,A. (Eds). (2007). Izmeneniye klimata [Climate Change.]. Obobshchayushchiy doklad. Vklad rabochikh grupp I, II, III v Chetvertyy doklad ob otsenke Mezhpravitel'stvennoy gruppy ekspertov po izmeneniyu klimata [Synthesis Report. Contribution of Working Groups I, II, III to the Fourth Assessment Report of the Intergovernmental Panel on Climate Change]. Zheneva, Shveytsariya: MGEIK. [in Russian].

9. Ivashchenko, O.O. \& Rudnyk-Ivashchenko, O.O. (2011). Napryamy adaptatsiyi ahrarnoho vyrobnytstva do zmin klimatu [Directions of adaptation of agricultural production to climate change]. Visnyk ahrarnoyi naukyBulletin of Agricultural Science, 8, 10-12 [in Ukrainian].
10. Kovalenko, A.M. (2012). Adaptatsiya zemlerobstva stepovoyi zony do pidvyshchennya posushlyvosti klimatu [Adaptation of agriculture in the steppe zone to increase the aridity of the climate]. Mizhvidomchyy tematychnyy naukovyy zbirnyk "Zroshuvane zemlerobstvo" - Interdepartmental thematic scientific collection "Irrigated agriculture", 58, 21-23 [in Ukrainian].

11. Kononova, N.K. (2002). Fluktuatsii tsirkulyatsii atmosfery Severnogo polushariya za 1899-2002 gg. Ekstremalnyye periody [Fluctuations of atmospheric circulation in the Northern Hemisphere for 1899-2002 Extreme periods]. Materialy Vsemirnoy konferentsii po izmeneniyu klimata [Proceedings of the World Conference on Climate Change]. (p. 411). Moscow [in Russian].

12. Krasylovets, Yu.H. et al. (2009). Zmina klimatu i optymizatsiya stroku sivby ozymoyi pshenytsi [Izmeneniye klimata i optimizatsiya sroka seva ozimoy pshenitsy]. Visnyk ahrarnoyi nauky - Vestnik agrarnoy nauki, 11, 16-19 [in Ukrainian].

13. Netis, I.T. (1994). Zmina klimatu $v$ zoni zroshennya [Climate change in the irrigation zone]. Zroshuvane zemlerobstvo - Irrigation agriculture, 39, 7-11 [in Ukrainian].

14. Novakovskyy, A.H. et al. (2007). Rekomendatsiyi z pidhotovky ta provedennya sivby ozymykh kultur u stepovomu rehioni pid urozhay 2007 roku [Recommendations for preparation and sowing of winter crops in the steppe region for the 2007 harvest]. Odesa [in Ukrainian].

15. Solodushko, M.M., Solodushko, V.F., Gasanova, I.I. \& Yaroshenko, S.S. (2019). Kosmichnyy monitorynh posushlyvykh yavyshch [Influence of the terms of sowing of winter barley after various precursors on its development and yield]. Ahronom - Agronomist, 3, 106 [in Ukrainian].

16. Tarariko, O.H. Syrotenko, O.V., Ilyenko, T.V. \& Velychko, V.A. (2012). Kosmichnyy monitorynh posushlyvykh yavyshchp [Space monitoring of droughts]. Visnyk ahrarnoyi nauky - Bulletin of Agricultural Science, 10, 16-20 [in Ukrainian].

17. Cherenkov, A.V. Bondarenko, A.S. \& Benda, R.V. (2011). Winter hardiness of winter barley plants depending on sowing time in the northern part of the steppe. Ahronom - Agronomist, 3, 111 [in Ukrainian].

Кисіль Л.Б., Заєць С.О. Вплив погодних умов та строків сівби на врожайність сортів ячменю озимого на зрошуваних землях Південного Степу України

Мета. Дослідити вплив агрометеорологічних умов і строків сівби на фрормування врожайності сортів ячменю озимого за вирощування на зрошуваних землях Півдня України. Методи. Дослідження проводилися в Інституті зрошуваного землеробства НААН в 2016-2019 рр. за методиками польових і лабораторних досліджень на зрошуваних землях (I33 НАAН, 2014). Технологія вирощування ячменю озимого загальноприйнята для зрошуваних умов зони. Результати. Установлено, що за роками досліджень агрометеорологічні умови весняно-літнього періоду вегетації ячменю озимого помітно різнилися. У 2017, 2018 і 2019 рр. за цей період температура повітря була вищою на $1,5,2,4$ і $2,5^{\circ} \mathrm{C}$, а опа- 
дів випало відповідно на 19,1 і 26,4 мм менше та на 80,7 мм більше за норму. За таких погодних умов сорти ячменю озимого Академічний і Дев'ятий вал вищу врожайність формували за сівби 1 жовтня. У 2017 р. сівба 1 жовтня порівняно з 20 жовтня підвищувала врожайність сорту Академічний на 13,3\%, а Дев'ятий вал - на 14,5\%. В умовах 2018 р. на сорті Академічний різниця була ще більшою і становила $38,0 \%$, а на Дев'ятому валі - 11,1\%. Найменшу різницю отримано у 2019 р., де вона дорівнювала 8,5\% на сорті Академічний і 4,9\% на Дев'ятому валі. Серед сортів вищою врожайністю зерна виділявся Дев'ятий вал - 6,83 т/га, що на 0,36 т/га вище, ніж на Академічному. Висновки. Погодні умови в роки проведення досліджень по-різному впливали на строки сівби та врожаю зерна нових сортів ячменю озимого. Установлено, що найбільшу врожайність зерна сорти ячменю озимого Академічний і Дев'ятий вал формували за сівби 1 жовтня, що в середньому більше на $20 \%$ і 10\%, ніж за сівби 20 жовтня. У середньому за три роки найвищу врожайність 6,83 т/га забезпечував сорт-дворучка Дев'ятий вал.

Ключові слова: агрометеорологічні умови, ячмінь озимий, сорти, строки сівби, зрошення.

Kysil L.B., Zaets S.A. Influence of weather conditions and sowing dates on the yield of winter barley varieties on irrigated lands of the Southern Steppe of Ukraine

Purpose. To study the influence of agrometeorological conditions and sowing dates on the formation of the yield of winter barley varieties for growing on irrigated lands in the south of Ukraine. Methods. The research was conducted at the Institute of Irrigation Agriculture of the NAAS in 2016-using the methods of field and laboratory research on irrigated lands (IIA NAAS, 2014). The technology of growing winter barley is generally accepted for the irrigated conditions of the zone. Results. It was found that during the years of research, the weather conditions of the springsummer growing season of winter barley were noticeably different. In 2017, 2018 and 2019, during this period, the air temperature was higher by $1.5,2.4$ and $2.5^{\circ} \mathrm{C}$, and precipitation fell by 19.1 and $26.4 \mathrm{~mm}$ less and $80.7 \mathrm{~mm}$ more, respectively the norm. Under such weather conditions, the varieties of winter barley Akademichnyi and Dev'iatyi val formed high yields when sowing on October 1. In 2017, sowing on October 1, compared to October 20, increased the yield of the Akademichnyi variety by $13.3 \%$, and the Dev'iatyi val - by $14.5 \%$. Under the conditions of 2018 , the difference on the Akademichnyi variety was even greater and amounted to $38.0 \%$, and on the Dev'iatyi val $-11.1 \%$. The smallest difference was in 2019 , where it was $8.5 \%$ on the Akademichnyi variety and $4.9 \%$ on the Dev'iatyi val. Among the varieties with a high grain yield, the Dev'iatyi val stood out $-6.83 \mathrm{t} / \mathrm{ha}$, which is $0.36 \mathrm{t} / \mathrm{ha}$ higher than in Akademichnyi. Conclusions. The weather conditions during the years of the research had a different effect on the sowing time and grain yield of winter barley varieties. It has been established that the highest grain yield of the Akademichnyi and Dev'iatyi val varieties was formed when sowing on October 1 , which is on average 20 and $10 \%$ more than when sowing on October 20. On average, over three years, the highest yield of $6.83 \mathrm{t} / \mathrm{ha}$ was provided by the two-handed variety Dev'iatyi val.

Key words: agrometeorological conditions, winter barley, varieties, sowing time, irrigation. 